\title{
Production and Characterization of Endo-Polygalacturonase from Aspergillus niger in Solid-state Fermentation in Double-Surface Bioreactor
}

\author{
Diogo Henrique Hendges*, Queli Montanari, Eloane Malvessi and Mauricio Moura da \\ Silveira \\ Instituto de Biotecnologia; Universidade de Caxias do Sul; C. P.: 1352; 95001-970; Caxias do Sul-RS - Brasil
}

\begin{abstract}
Endo-polygalacturonase (endo-PG) production by Aspergillus niger T0005/007-2 in solid medium with $170 \mathrm{~mm}$ of height was evaluated in a cylindrical double surface bioreactor in 96- $h$ experiments. Cell concentration close to 92 $m g . g^{-1} d m$ (mg per $g$ of dry medium) in the standard condition (static) was achieved, whereas in tests under forced aeration of 1.4 and $2.8 \mathrm{~L}_{\mathrm{min}} \mathrm{m}^{-1} \mathrm{Kg}^{-1} \mathrm{~mm}$ ( $\mathrm{L}$ of air per minute per $\mathrm{Kg}$ of moist medium) and with the central shaft fungal biomass attained approximately $100 \mathrm{mg} \cdot \mathrm{g}^{-1} \mathrm{dm}$. Superior endo-PG activity was obtained with the centralshaft system, $78 \mathrm{U} \cdot \mathrm{g}^{-1} \mathrm{dm}$ (units per $\mathrm{g}$ of dry medium). Forced aeration and pressure pulse showed no positive effect on the production of endo-PG, $45 \mathrm{U} \cdot \mathrm{g}^{-1} \mathrm{dm}$ and $28 \mathrm{U} \cdot \mathrm{g}^{-1} \mathrm{dm}$, respectively. None of the conditions evaluated was efficient for medium temperature control. Endo-PG was stable up to $40^{\circ} \mathrm{C}$. The activity decreased in $50 \%$ after 120 minutes at $50^{\circ} \mathrm{C}$, which is a temperature normally found during this process.
\end{abstract}

Key words: Aspergillus niger, double-surface bioreactor, endo-polygalacturonase, solid-state fermentation, enzyme stability

\section{INTRODUCTION}

Pectinases are enzymes that break down pectic substances and include two groups deesterefication and depolymerization enzymes. Endo-polygalacturonase (endo-PG) is a depolymerizing enzyme, which is used in food, textile and paper industries (Kashyap et al., 2001; Kaur et al., 2004). In association with cellulases, endo-PG is used for essential oil extraction (Pedruzzi et al., 2001).

In solid-state fermentation (SSF), the microorganisms grow over a moist solid matrix, which simulates their natural conditions (Pandey,
2003; Hölker and Lenz, 2005; Singhania et al., 2009). SSF uses simple medium and low moist content; however, mass and heat transfer are limited by simple diffusion (Mitchell et al., 1992). Different configurations of SSF bioreactors have been described, such as rotating drum, column, and tray reactors. The last one is widely used at industrial scale (Mitchell et al., 1992; Mitchell et al., 2000; Durand, 2003). New designs have been tried to improve mass and heat transfer (Schmidell and Facciotti, 2001; Singhania et al., 2009; Mitchell et al., 2010). The efficient temperature control in Bacillus thuringiensis CM-1 cultivation in an aerated tray bioreactor with internal

*Author for correspondence: diogo@utfpr.edu.br 
circulation of air was reported by Hongzhang et al. (2002), who observed temperature gradients of only $0.5^{\circ} \mathrm{C}$ during the process. Using a similar design, Fujian et al. (2002) reported that $0.20 \mathrm{MPa}$ pressure coupled to internal air circulation favored heat and mass transfer in Penicillium decumbens JUA 10 culture. Tao et al. (1999) showed the positive influence of internal pressure over heat and mass transfer in tray reactor culture of Trichoderma viride SL-1. Pulsed bioreactor facilitated the heat dissipation during the cultivation of Bacillus pumillus 1.1625 for protease production (Aijun et al., 2005).

Aeration rate and gas composition into the reactor influenced Aspergillus niger growth and protease formation in SSF (Villegas et al., 1993). Mo et al. (2004) observed that air flow rate of $7 \mathrm{~L}^{\mathrm{min}}{ }^{-1}$ facilitated the production of cellulase by $P$. decumbens, whereas a higher flow $\left(10\right.$ L.min $\left.{ }^{-1}\right)$ affected negatively the processs, probably due to the drying of the medium.

This work aimed to study the production of endopolygalacturonase (endo-PG), a hydrolase of the pectinase group, by Aspergillus niger T0005/007-2 in solid-state fermentation in double-surface bioreactor (DSB). In this system, the use of different air flow rates, the application of pressure pulses coupled to forced aeration, and the adaptation of a central shaft to the medium bed were tested and the effects of these conditions on cell growth, enzyme production, and temperature control were assessed.

\section{MATERIALS AND METHODS}

\section{Microorganism}

Aspergillus niger T0005/007-2 was obtained from the Departamento de Bioquímica, Fundação Universidade Federal de Rio Grande (FURG-RS) and used in this work. For microorganism maintenance and spore production, a medium described by Maiorano (1982) was used.

\section{Culture medium and inoculum}

The culture medium was formulated with wheat bran $(35.6 \% \mathrm{w} / \mathrm{w})$, citric pectin (Farmaquímica Porto Alegre, RS, Brazil) (3.0\% w/w), glucose $(9.4 \% \mathrm{w} / \mathrm{w})$, and nutrients salts solution $(29.6 \%$ $\mathrm{v} / \mathrm{w})$, sterilized at $1 \mathrm{~atm}$ for 20 minutes.

Inoculation was done with suspensions of $A$. niger spores to provide a concentration of $10^{7}$ spores. $^{-1}$ of moist medium and a moisture content of approximately $60 \%$.

\section{Experimental conditions}

The double-surface bioreactor (DSB) used in this work was built with a PVC tube with $300 \mathrm{~mm}$ height $x 100 \mathrm{~mm}$ diameter. Inside the tube, a nylon grid was installed at $65 \mathrm{~mm}$ from the bottom to hold the solid medium. In all experiments, the height of medium bed was $170 \mathrm{~mm}$. Lateral holes allowed temperature measurement in different regions of the medium during the process.

As standard condition, both sides of DSB were covered with a thin layer of gauze, which allowed gas and heat changes with the external environment by simple diffusion.

Alternatively, DSB was operated under forced aeration through the medium, aiming to improve mass and heat transfer. In this case, both sides of DSB were closed with PVC covers and air inlet and gas outlet tubes were adapted to the extremities of the reactor. The air to be introduced in DSB was previously filtered and driven through a humidifier column to heat and saturate with water. Three flow rates were evaluated: $1.4,2.8$ and $8.5 \mathrm{~L} \cdot \mathrm{min}^{-1} \cdot \mathrm{Kg}^{-1} \mathrm{~mm}$ (liters of air per minute per $\mathrm{Kg}$ of moist medium).

Another configuration tested for DSB was a pressure pulse system. For this purpose, the gas outlet duct was closed, causing the increase of the internal pressure up to $0.5 \mathrm{~atm}$, and then opened to allow the instant decompression. The aim of this procedure was to expand the solid medium layer and improve heat and mass transfer through it. Similar designs have been described earlier in the literature (Tao et al., 1999; Zhao et al., 2001; Hongzhang et al., 2002; Zhang et al., 2003; Mo et al., 2004; Aijun et al., 2005).

Furthermore, the adaptation of a central shaft system to the bed medium, without aeration, was evaluated. The shaft was built with an 8 mesh screen, with $10 \mathrm{~mm}$ diameter and $170 \mathrm{~mm}$ height. In this experiment, the conditions were the same of the standard experiment.

All these processes were carried out in humidity saturated stove at $30^{\circ} \mathrm{C}$ for $96 \mathrm{~h}$.

\section{ANALYTICAL METHODS}

Microorganism growth was indirectly estimated from oxygen balance data as described by 
Zabriskie and Humprey (1978) and adapted to $A$. niger solid cultivation by Fontana (2005).

The moisture content of the medium was determined gravimetrically (A.O.A.C., 1998) with $1.0 \mathrm{~g}$ sample. To the dried sample, $10 \mathrm{~mL}$ of distilled water was added and the $\mathrm{pH}$ was measured in the liquid phase.

Endo-PG activity was estimated by the reduction of viscosity of a citric pectin solution $(0.63 \% \mathrm{w} / \mathrm{v})$ in acetate buffer $(0.05 \mathrm{M}, \mathrm{pH} 4.0)$ at $30^{\circ} \mathrm{C}$ for 30 $\mathrm{min}$. One unit of endo-PG was defined as the amount of enzyme that reduced the solution viscosity by $50 \%$ under assay conditions (Maiorano, 1990).

Endo-PG activity and thermostability were evaluated by varying the temperature from 20 to $70^{\circ} \mathrm{C}$ and from 25 to $70^{\circ} \mathrm{C}$, respectively. In thermostability tests, the maximum time of crude broth exposure to each temperature evaluated was 120 minutes, the samples being taken every 15 minutes during the first hour of test and then every 30 minutes.

The results regarding fungal growth and enzyme formation were compared statistically by one-way ANOVA and Tukey test with 5\% level.

\section{RESULTS AND DISCUSSION}

With the operating conditions of the DSB, lower colonization of the medium was achieved in the standard condition compared to the process carried out under forced aeration and with the central shaft and better than pressure pulse system.

The variation of biomass concentration of $A$. niger during the process in different experiments is presented in Figure 1. Maximum biomass concentration obtained under the standard condition was $92 \mathrm{mg} \cdot \mathrm{g}^{-1} \mathrm{dm}$ (mg per g of dry medium). With forced aeration system of 1.4 and $2.8 \mathrm{~L} \cdot \mathrm{min}^{-1} \cdot \mathrm{Kg}^{-1} \mathrm{~mm}$ and with the shaft system, an increase in the biomass concentration to approximately $100 \mathrm{mg} \cdot \mathrm{g}^{-1} \mathrm{dm}$ was observed. This increase could be associated due to the better colonization found in the deeper regions of the medium bed.

When a flow rate of $8.5 \mathrm{~L} \cdot \mathrm{min}^{-1} \cdot \mathrm{Kg}^{-1} \mathrm{~mm}$ was employed, the microorganism growth decreased (76 mg. $\mathrm{g}^{-1} \mathrm{dm}$ ), probably due to drying observed in both surfaces of the medium bed, indicating that the air humidifier system was not efficient for this high flow rate. Mo et al. (2004) reported that high air flow rates affected $P$. decumbens growth and cellulase production.

With the pressure pulse system, the fungal growth decreased (28 $\left.\mathrm{U}^{-1} \mathrm{dm}\right)$ possibly as a consequence of mycelium disruption when the pressure shock was applied, as also observed by Hongzhang et al. (2005), reaching $73 \mathrm{mg} \cdot \mathrm{g}^{-1} \mathrm{dm}$. Table 1 resumes the results of fungal growth at $96 \mathrm{~h}$ of process.

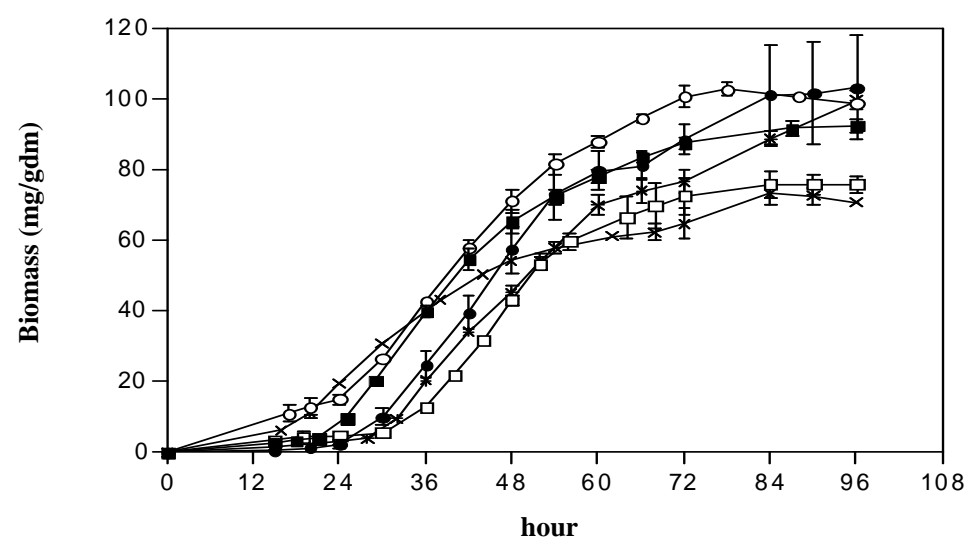

Figure 1 - Biomass variation during the process in solid-state culture of Aspergillus niger under the

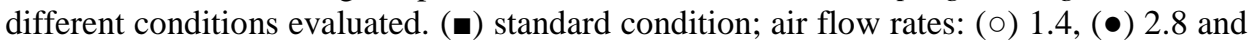
( $\square$ ) $8.5 \mathrm{~L} \cdot \mathrm{min}^{-1} \cdot \mathrm{Kg}^{-1} \mathrm{~mm} ;(\times)$ pressure pulses coupled to the forced aeration $\left(1.4 \mathrm{~L} . \mathrm{min}^{-}\right.$ $\left.{ }^{1} . \mathrm{Kg}^{-1} \mathrm{~mm}\right) ;(*)$ central shaft. 
Table 1 - Maximum biomass concentration reached in the different experiments.

\begin{tabular}{cc}
\hline Condition & Biomass $\left(\mathbf{m g} \cdot \mathbf{g}^{-1} \mathbf{d m}\right)$ \\
\hline Standard Condition & $92.3^{\mathrm{b}} \pm 2.54$ \\
$1.4 \mathrm{~L} \cdot \mathrm{min}^{-1} \cdot \mathrm{Kg}^{-1} \mathrm{mu}$ & $103^{\mathrm{a}} \pm 2.54$ \\
$2.8 \mathrm{~L} \cdot \mathrm{min}^{-1} \cdot \mathrm{Kg}^{-1} \mathrm{mu}$ & $103^{\mathrm{a}} \pm 20.9$ \\
$8.5 \mathrm{~L} \cdot \mathrm{min}^{-1} \cdot \mathrm{Kg}^{-1} \mathrm{mu}$ & $75.8^{\mathrm{c}} \pm 3.57$ \\
Pressure pulse system & $73.3^{\mathrm{c}} \pm 4.74$ \\
Central shaft & $99.7^{\mathrm{a}} \pm 3.74$ \\
\hline
\end{tabular}

Biomass $^{\mathrm{a}, \mathrm{b}, \mathrm{c}}-$ different letters are statistically different at 5\% level.

As shown in Table 2, maximum enzyme activity was obtained with the central shaft system adapted to the medium bed after $96 \mathrm{~h}$ of process $(78 \mathrm{U.g}$ ${ }^{1} \mathrm{dm}$, which was about $25 \%$ higher than that achieved under the standard condition $(63 \mathrm{U} . \mathrm{g}$ $\left.{ }^{1} \mathrm{dm}\right)$. The last one was similar to the obtained with forced aeration with flow rate of $1.4 \mathrm{~L} \cdot \mathrm{min}^{-1} \cdot \mathrm{Kg}^{-}$ ${ }^{1} \mathrm{~mm}$. With pressure pulse system, a significant decrease in enzyme production was found ( $28 \mathrm{U.g}$ ${ }^{1} \mathrm{dm}$ ), following the inferior cell growth attained in this experiment.

Table 2 - Maximum endo-PG activity in the different experiments.

\begin{tabular}{ccc}
\hline Condition & Endo-PG $\mathbf{~ ( U . g ^ { - 1 } \mathbf { d m } )}$ & Time $(\mathbf{h})$ \\
\hline Standard & $63.2^{\mathbf{b}} \pm 4.03$ & 96 \\
$1.4 \mathrm{~L} \cdot \mathrm{min}^{-1} \cdot \mathrm{Kg}^{-1} \mathrm{mu}$ & $62.6^{ \pm} \pm 1.58$ & 96 \\
$2.8 \mathrm{~L} \cdot \mathrm{min}^{-1} \cdot \mathrm{Kg}^{-1} \mathrm{mu}$ & $54.8^{\mathrm{c}} \pm 14.8$ & 96 \\
$8.5 \mathrm{~L} \cdot \mathrm{min}^{-1} \cdot \mathrm{Kg}^{-1} \mathrm{mu}$ & $44.9^{\mathrm{d}} \pm 1.70$ & 96 \\
Pressure pulse system & $28.0^{\mathrm{e}} \pm 6.78$ & 72 \\
Central shaft & $78.5^{ \pm} \pm 3.39$ & 96 \\
\hline
\end{tabular}

Endo-polygalacturonase $^{\mathrm{a}, \mathrm{b}, \mathrm{c}, \mathrm{d}, \mathrm{e}}-$ different letters are statistically different at $5 \%$ level.

In this work, in all the experiments, no evident effect on the heat dissipation from medium bed of A. niger culture was found as described in the literature (Tao et al., 1999; Zhang et al., 2003; Mo et al., 2004; Aijun et al., 2005), since temperatures around $50^{\circ} \mathrm{C}$ were measured, between 36 and $41 \mathrm{~h}$ of process, remaining close to $46-47^{\circ} \mathrm{C}$ until the end of the cultivations. As such, one can suggest that the higher endo-PG activity obtained with a central shaft adapted to the bed medium was associated with the larger fungal growth, probably due to better mass transfer - oxygen supply and carbon dioxide release - to deeper settings of the bed. However, further studies using central shaft are needed to understand completely this system.

The influence of the temperature on endo-PG activity and thermostability was evaluated. As shown in Figure 2, among the different conditions tested, the maximum activity of endo-PG was found at $50^{\circ} \mathrm{C}$, which was approximately the double of the activity obtained under the standard analytical condition $\left(30^{\circ} \mathrm{C}\right)$. Malvessi and Silveira (2004) reported that temperatures between 35- $40^{\circ} \mathrm{C}$ were ideal for the activity of endo-PG produced by Aspergillus oryzae in submerged process.

Nevertheless, when this temperature $\left(50^{\circ} \mathrm{C}\right)$ was applied to estimate the thermostability of endo-PG, an enzyme inactivation of approximately $50 \%$ was observed after 120 minutes of treatment (Figure $3)$. On the other hand, after the same time of treatment at 25,30 and $40^{\circ} \mathrm{C}$, almost all enzyme activity was preserved. The total inactivation of endo-PG was quickly noticed after about 15 minutes at 60 and $70^{\circ} \mathrm{C}$, as reported by Naidu and Panda (2003) for polygalacturonase produced by A. niger in submerged process. This study corroborated the conclusions reported by Daniel (1996), who suggested the low stability of enzymes at temperatures higher than the ideal for the microbial growth.

By comparing the results found in these tests, particularly those performed at 40 and $50^{\circ} \mathrm{C}$, one can confirm the importance of fermentation temperature control to avoid, or to reduce, enzyme denaturation during the own production process. 


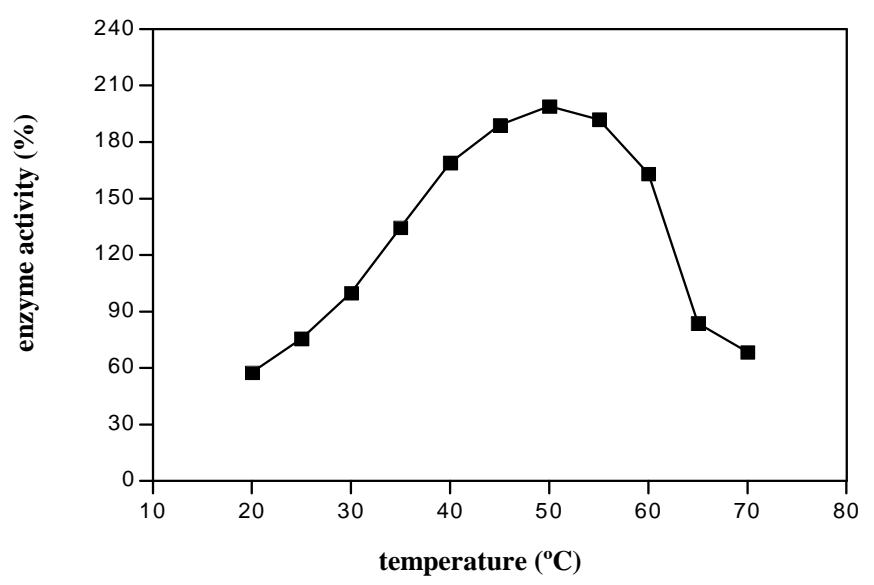

Figure 2 - Variation of endo-PG activity produced by Aspergillus niger in solid-state fermentation with the temperature. The value of $100 \%$ presents the standard conditon of enzyme reaction $\left(30^{\circ} \mathrm{C}\right)$.

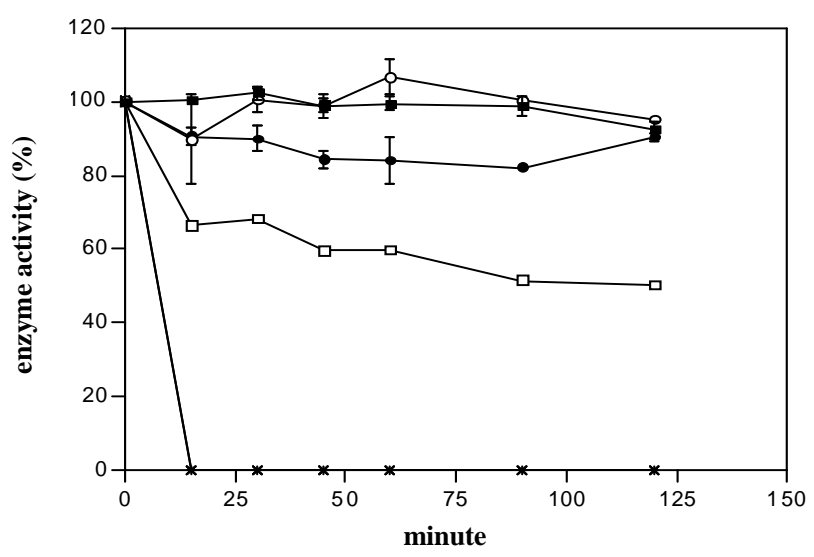

Figure 3 - Thermostability of endo-PG produced by Aspergillus niger in solid-state fermentation after previous treatment at different temperatures. (ロ) $20^{\circ} \mathrm{C},(\circ) 30^{\circ} \mathrm{C},(\bullet) 40^{\circ} \mathrm{C},(\square)$ $50^{\circ} \mathrm{C},(\times) 60^{\circ} \mathrm{C} ;(*) 70^{\circ} \mathrm{C}$.

\section{CONCLUSIONS}

The results of the present work showed that the use of strategies such as forced aeration or air pressure pulses had no positive effect on the production of endo-polygalacturonase by the strain T0005/007-2 of A. niger in comparison to static conditions.

From the data obtained, it is possible to suggest that the use of one or more perforated shafts along a double-surface bioreactor is a simple and more efficient solution to the task of improving mass transfer in solid-state fermentations.

For temperature control, however, further efforts are needed to develop a simple bioreactor design that allows an efficient heat release from the medium. In this case, it is interesting to highlight the remarkable difference in endo-PG stability at 40 and $50^{\circ} \mathrm{C}$ indicating that even a small improvement in temperature control could lead to substantial gains in production by avoiding enzyme denaturation.

\section{ACKNOWLEDGMENTS}

The authors acknowledge the Fundação de Amparo à Pesquisa do Estado do Rio Grande do Sul (FAPERGS), the Coordenação de Aperfeiçoamento de Pessoal de Nível Superior (CAPES) and the Universidade de Caxias do Sul (UCS) for the financial support of this work. 


\section{REFERENCES}

Aijun, Z. Hongzhang, C.; Zuohu, L. (2005), Air pressure pulsation solid state production of alkaline protease by Bacillus pumilus 1.1625. Proc. Biochem., 40, 15471551.

A.O.A.C. (1998), Official Methods of Analysis of A.O.A.C. International. 16th ed.Gaithersburg, Maryland.

Daniel, R. M. (1996), The upper limits of enzyme thermal stability. Enz. Microb. Technol., 19, 74-79.

Durand, A. (2003), Bioreactor designs for solid state fermentation. Biochem. Eng. J., 13, 113-125.

Fontana, R. C.; Salvador, S.; Silveira, M. M. (2005), Influence of pectin and glucose on growth and polygalacturonase production by Aspergillus niger in solid-state cultivation. J. Ind. Microbiol. Biotechnol., 32, 371-377.

Fujian, X.; Hongzhang, C.; Zuohu, L. (2002), Effect of periodically dynamic changes of air on cellulose production in solid-state fermentation. Enzyme Microb. Tech., 30, 45-48.

Hölker, U. and Lenz, J. (2005), Solid-state fermentation are there any biotechnological advantages? Curr. Opin. Microbiol., 8, 301-306.

Hongzhang, C.; Fujian, X.; Zhonghou, T.; Zuohu, L. (2002), A novel industrial-level reactor with two dynamic changes of air for solid-state fermentation. $J$. Biosc. Bioeng., v.93, 2, 211-214.

Kashyap, D. R.; Vohra, P. K.; Chopra, S.; Tewari, R. (2001), Applications of pectinases in the commercial sector: a review. Bioresour. Technol., 77, 215-227.

Kaur, G.; Kumar, S.; Satyanarayana, T. (2004), Production, characterization and application of a thermostable polugalacturonase of a thermophilic mould Sporotrichum thermophile Aipinis. Bioresour. Technol., 94, 239-243.

Linde, G. A. (2000), Produção de pectinase por fermentação semi-sólida biorreator de coluna. Dissertação de mestrado. Fundação Universidade Federal do Rio Grande. Rio Grande, Rio Grande do Sul, Brasil.

Maiorano, A. E. (1990), Produção de pectinase por fermentação em estado sólido. Tese de Doutorado. Escola Politécnica da Universidade de São Paulo. São Paulo, São Paulo, Brasil.

Maiorano, A. E. (1982), Influência da concentração de inoculo e da temperatura na produção de enzimas amilolíticas por cultivo de Aspergillus niger em emio semi-sólido. Dissertação de Mestrado. Escola Politécnica da Universidade de São Paulo. São Paulo, São Paulo, Brasil.

Malvessi, E.; Silveira, M. M. (2004), Influence of medium composition and $\mathrm{pH}$ on the production of polygalactuoronases by Aspergillus oryzae. Braz. Arch. Biol. Technol., v.47, 5, 693-702.
Miller, G.L. (1959), Use of dinitrosalicylic acid reagent for determination of reducing sugar. Anal. Chem., 31, 426.

Mitchell, D. A.and Losane, B. K. (1992), Definition, characterization and potential. In-Solid substrate cultivation. Doelle, H. W.; Mitchell, D. A.; Rolz, C. E. Elsevier Science Publishers LTD.

Mitchell, D. A.; Krieger, N.; Stuart, D. M.; Pandey, A. (2000), New developments in solid-state fermentation II. Rational approaches to the dsign, operation and scale-up of bioreactors. Proc. Biochem., 35, 1211-1225.

Mitchell, D. A.; Cunha, L. E. N.; Machado, A. V. L.; Luz Jr., L. F. L.; Krieger, N. (2010), A model-based investigation of the potencial advantages of multi-layer packed beds in solid-state fermentation. Biochem. Eng. J., 48, 195-203.

Mo, H.; Zhang, X. Li, Z. (2004), Control of gas phase for enhanced cellulose production by Penicillium decumbens in solid-state culture. Proc. Biochem., 39, 1293-1297.

Naidu, G. S. and Panda, T. (2003), Studies on pH and thermal deactivation of pectolytic enzymes from Aspergillus niger. Biochem. Eng. J., 16, 57-67.

Pandey, A. (2003), Solid-state fermentation. Biochem. Eng. J., 13: 81-84.

Pedruzzi, I.; Agostini, F.; Dillon, A.J.P. and Silveira, M.M. (2001), Extração de óleo essencial de limão Taiti (Citrus latifolia) com pectinases e celulases. In-VII Seminário Brasileiro de Hidrólise Enzimática de Biomassa (VII SHEB) (2001), CD-ROM. Maringá, Paraná, Brasil.

Schmidell, W.; Facciotti , M. C. R. (2001), In-Schmidell, W.; Lima, V.; Aquarone, E.; Borzani, W. Biotecnologia Industrial. Edgard Blücher Ltda. Vol. 2, pp.179-184.

Singhania, R. R.; Patel, A. K.; Soccol, C. R.; Pandey, A. (2009), Recent andvances in solid state fermentation. Biochem. Eng. J., 44, 13-18.

Tao, S.; Beihui, L.; Zuohu, L.; Deming, L. (1999), Effects of air pressure amplitude on cellulase productivity by Trichoderma viride SL-1 in periodic pressure solid state fermenter. Proc. Biochem., 34, 25-29.

Villegas, E.; Aubague, S.; Alcântara, L.; Auria, R.; Revah, S. (1993), Solid state fermentation: acid protease production in controlled $\mathrm{CO}_{2}$ and $\mathrm{O}_{2}$ enviroments. Biotech. Adv., 11, 387-397.

Zabriskie, D.; Humphrey, A. E. (1978), Real time estimation of aerobic and haze formation in fruit juices. AIHE J., 24, 138-146.

Zhang, X.; Mo, H.; Zhang, J.; Li, Z. (2003), A solid-state bioreactor coupled with forced aeration and pressure oscillation. Biotecnol. Lett., 25, 417-420.

Zhao, H.; Zhang, X.; Zhou, X.; Li, Z. (2001), Effects of air pressure oscillation amplitude on oxygen transfer rate and biomass productivity in a solid-state fermenter. Biotechnol. Lett., 23, 1197-1200.

Received: August 28, 2009; Revised: February 02, 2010; Accepted: September 14, 2010. 